\title{
Theoretical investigation of structural, energetic and electronic properties of titanate pyrochlores
}

\author{
H Y Xiao ${ }^{1,2,4}$, L M Wang 2 , X T Zu ${ }^{1}$, Jie Lian ${ }^{3}$ and Rodney C Ewing ${ }^{3}$ \\ ${ }^{1}$ Department of Applied Physics, University of Electronic Science and Technology of China, \\ Chengdu 610054, People's Republic of China \\ 2 Department of Nuclear Engineering and Radiological Sciences, University of Michigan, \\ Ann Arbor, MI 48109-2104, USA \\ ${ }^{3}$ Departments of Geological Science and Materials Sciences and Engineering, University of \\ Michigan, Ann Arbor, MI 48109-1005, USA \\ E-mail: hyxiao@uestc.edu.cn
}

Received 23 February 2007, in final form 28 June 2007

Published 20 July 2007

Online at stacks.iop.org/JPhysCM/19/346203

\begin{abstract}
$A b$ initio total energy calculations using the plane-wave pseudopotential method based on density functional theory were carried out to investigate the structural, energetic and electronic properties of $\mathrm{A}_{2} \mathrm{Ti}_{2} \mathrm{O}_{7}(\mathrm{~A}=\mathrm{La}, \mathrm{Gd}$ and $\mathrm{Yb}$ ) pyrochlores. It turned out that the formation energies of antisite defects are not linearly dependent on the ratio of the cation radii, and, for the three compositions, the cation antisite formation energy is largest for $\mathrm{Gd}_{2} \mathrm{Ti}_{2} \mathrm{O}_{7}$ pyrochlore. It was indicated that $\mathrm{Gd}_{2} \mathrm{Ti}_{2} \mathrm{O}_{7}$ compound is the least likely to form defect fluorite structure, which gives rise to the least resistance to radiationinduced amorphization. DOS analysis showed that stronger interaction exists in the $\mathrm{Gd}_{2} \mathrm{Ti}_{2} \mathrm{O}_{7}$ compound, and its electronic structure is very different from that of $\mathrm{La}_{2} \mathrm{Ti}_{2} \mathrm{O}_{7}$ and $\mathrm{Yb}_{2} \mathrm{Ti}_{2} \mathrm{O}_{7}$. Our calculations suggested that the electronic structure of the A cation and bond type should be taken into account when explaining the response behavior of $\mathrm{A}_{2} \mathrm{Ti}_{2} \mathrm{O}_{7}(\mathrm{~A}=\mathrm{La}, \mathrm{Gd}, \mathrm{Yb})$ pyrochlores to ion irradiation-induced amorphization.
\end{abstract}

\section{Introduction}

In the past several years there has been considerable interest in rare earth pyrochlores, both scientifically and technologically. Pyrochlore has a remarkable variation of properties such as dielectric, piezoelectric and ferroelectric properties [1], and some pyrochlores exist as insulators or semiconductors [2]. Also, the pyrochlore-type system offers ceramics for nuclear applications [3]. Experimentally, radiation effects in a wide range of pyrochlore compositions have been extensively investigated due to the potential application of pyrochlores as host

4 Author to whom any correspondence should be addressed. 
matrices for the immobilization of actinides-particularly $\mathrm{Pu}$ [4]. To simulate the radiation damage resulting from the $\alpha$-decay events of incorporated radionuclides, numerous ion-beamirradiation studies [4-15] have been carried out. Both heavy- and light-ion irradiations were performed at controlled temperatures, and in situ irradiations, combined with cross-sectional transmission electron microscopy, were used to examine the microstructural evolution upon ion-beam damage.

Experimentally, single crystals of the entire series of $\mathrm{A}_{2} \mathrm{Ti}_{2} \mathrm{O}_{7}(\mathrm{~A}=\mathrm{Sm}$ to $\mathrm{Lu}$, and $\mathrm{Y})$ pyrochlore compounds were irradiated by $1 \mathrm{MeV} \mathrm{Kr}^{+}$ions at temperatures from 293 to $1073 \mathrm{~K}$, and the microstructure evolution, as a function of increasing radiation fluence, was characterized using in situ transmission electron microscopy (TEM) [4-15]. It was found that the critical amorphization temperature, $T_{\mathrm{c}}$, generally increases from $\sim 480$ to $\sim 1120 \mathrm{~K}$ with increasing A-site cation size (e.g. $0.977 \AA$ for $\mathrm{Lu}^{3+}$ to $1.079 \AA$ for $\mathrm{Sm}^{3+}$ ). However, an abnormally high susceptibility to ion beam damage was found for $\mathrm{Gd}_{2} \mathrm{Ti}_{2} \mathrm{O}_{7}$ (with the highest $T_{\mathrm{c}}$ of $\left.\sim 1120 \mathrm{~K}\right)[4,9,10,16]$. A molecular dynamics simulation method has been employed to predict the stability of pyrochlore compounds [17]. The factors influencing the response of titanate pyrochlores to ion irradiation-induced amorphization have been generally ascribed to the cation radius ratio and defect formation energy (i.e. the tendency to undergo an orderdisorder transition to the defect-fluorite structure). On the other hand, Lian et al $[4,9,10,16]$ suggested that the resistance of the pyrochlore structure to ion beam-induced amorphization is not only affected by the relative sizes of the A- and B-site cations, but also the electronic configuration of the cation and the structural disorder. Panero et al [18] carried out firstprinciples calculations on $\mathrm{Y}_{2}(\mathrm{Ti}, \mathrm{Sn}, \mathrm{Zr})_{2} \mathrm{O}_{7}$ pyrochlore. It was demonstrated that the defectformation energies are not simple functions of the cationic radius, and a significant influence of the electronic configuration of the A and B cations was observed. The power of first-principles methods applied to pyrochlore has also been illustrated by several other calculations [19, 20]. Although the electronic structure of ternary oxides $\mathrm{A}_{2} \mathrm{Ti}_{2} \mathrm{O}_{7}(\mathrm{~A}=\mathrm{Sm}-\mathrm{Er}, \mathrm{Yb}, \mathrm{Lu})$ has been investigated by Nemoshkalenko et al [21] using x-ray photoemission spectroscopy and x-ray emission spectra measurements, the effects of the electronic structures of A-site cations on their stability have not been explained.

Here, a plane-wave pseudopotential method was used to investigate the structural, energetic and electronic properties of $\mathrm{A}_{2} \mathrm{Ti}_{2} \mathrm{O}_{7}(\mathrm{~A}=\mathrm{La}, \mathrm{Gd}, \mathrm{Yb})$ pyrochlore. The major aims of the present work were to investigate the effects of the cation radii ratio and electronic structures of A-site cations, such as density of states, Hirshfeld charge and overlap population, on their stabilities. Our calculations suggested that the electronic structures of A-site cations have significant effects on the stability of titanate pyrochlores.

\section{Computational details}

Our calculations were carried out using VASP code. The plane-wave pseudopotential method within the density functional theory (DFT) framework was employed in this work. The electronic ground state was calculated with the residuum-minimization techniques and the geometric structure was optimized with the conjugated-gradient technique. The Perdew and Wang functional (known as PW91) within the generalized gradient approximation was used to describe the exchange-correlation potential energy $[22,23]$. The calculations were based on a primitive unit cell containing 22 atoms, while the calculations of defect formation energies are performed in a larger unit cell consisting of 88 atoms. We describe the interaction between ions and electrons using the projector augmented wave method [24], with the following atomic valence configurations: $\mathrm{La}\left(5 \mathrm{p}^{6}, 5 \mathrm{~d}^{1}, 6 \mathrm{~s}^{2}\right), \mathrm{Gd}\left(6 \mathrm{~s}^{2}, 5 \mathrm{p}^{6}, 5 \mathrm{~d}^{1}\right), \mathrm{Yb}\left(6 \mathrm{~s}^{2}, 5 \mathrm{p}^{6}, 5 \mathrm{~d}^{0}\right)$ and $\operatorname{Ti}\left(3 s^{2}, 4 s^{1}, 3 p^{6}, 3 d^{3}\right)$, where f-electrons are kept frozen in the core. The influences of different 


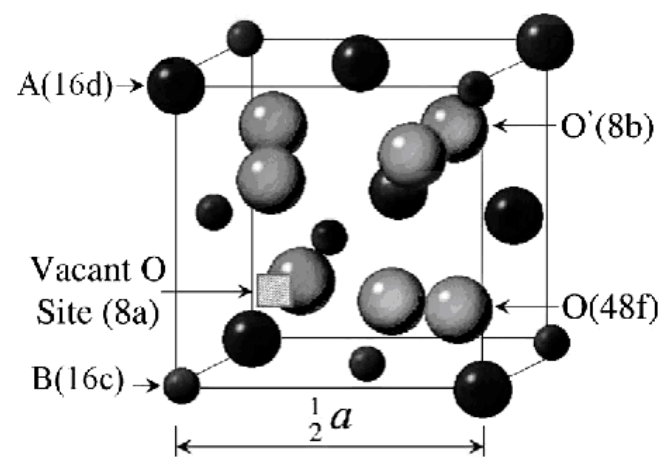

Figure 1. Schematic view of one-eighth of a unit cell of the pyrochlore structure.

$K$-point sampling and cutoff energy were explored in a series of test calculations, which led to our calculations being performed with $2 \times 2 \times 2 k$-point sampling and with the basis set for valence electrons consisting of plane waves with a cutoff energy of $400 \mathrm{eV}$.

\section{Results}

\subsection{Structural properties}

Rare earth oxide pyrochlores, of ideal stoichiometry $\mathrm{A}_{2} \mathrm{~B}_{2} \mathrm{O}_{6} \mathrm{O}^{\prime}$, crystallize in space group $F d 3 m$ with the unit cell containing eight molecules $(Z=8)$ and four crystallographically nonequivalent sites. If the origin is chosen at the $\mathrm{B}$ site, the atoms occupy the following special positions: $\mathrm{A}$ at $16 \mathrm{~d}\left(\frac{1}{2}, \frac{1}{2}, \frac{1}{2}\right), \mathrm{B}$ at $16 \mathrm{c}(0,0,0), \mathrm{O}$ at $48 \mathrm{f}\left(x, \frac{1}{8}, \frac{1}{8}\right)$ and $\mathrm{O}^{\prime}$ at $8 \mathrm{~b}\left(\frac{3}{8}, \frac{3}{8}, \frac{3}{8}\right)$. The structure type can be considered as an ordered defect fluorite structure. The A and B cations form the face-centered cubic array and are ordered into rows in the $\langle 110\rangle$ directions. The seven oxygen atoms are tetrahedrally coordinated by four random cations and evenly distributed over eight equivalent sites. In the pyrochlore structure, there are two different oxygen sites: six oxygen atoms at $48 \mathrm{f}$ sites are surrounded by two A cations and two B cations, while the seventh oxygen atom occupied at the $8 \mathrm{~b}$ site is surrounded by four A cations. The remaining unoccupied $8 \mathrm{a}$ site is surrounded by B cations. Finally, the $48 \mathrm{f}$ anions are shifted toward the smaller B cations by an amount defined by the $x$ (48f) positional parameter [25]. One-eighth of a unit cell of the pyrochlore structure is shown in figure 1. The pyrochlore structure can be completely described by the cubic lattice parameter, $a_{0}$, and the $48 \mathrm{f}$ oxygen positional parameter, $x$. Table 1 lists our calculated lattice constant $a_{0}$ and $x$ parameters, along with a comparison of our results with experimental and other theoretical values. It can be seen from table 1 that for $\mathrm{La}_{2} \mathrm{Ti}_{2} \mathrm{O}_{7}$ and $\mathrm{Gd}_{2} \mathrm{Ti}_{2} \mathrm{O}_{7}$ compounds our results agree well with most of theoretical calculations or experiments [9, 19, 20, 26-29], while the optimized lattice constant of $\mathrm{Yb}_{2} \mathrm{Ti}_{2} \mathrm{O}_{7}$ is about $1.67 \%$ larger than the experimental value [9]. Kennedy et al [30] have analyzed the structural and bonding trends in tin pyrochlore oxides and the single variable oxygen positional parameter was observed to decrease systematically with the increasing lattice parameter, while this trend was not observed from our calculations.

\subsection{Energetic properties}

The approach we employed allows us not only to study the perfect crystal lattice but also to predict the extent to which a given lattice accommodates point defects. Under irradiation, cation 
Table 1. Calculated structural parameters of $\mathrm{A}_{2} \mathrm{Ti}_{2} \mathrm{O}_{7}(\mathrm{~A}=\mathrm{La}, \mathrm{Gd}, \mathrm{Yb})$ compared with available experimental and theoretical values.

\begin{tabular}{lllllll}
\hline Compound & & $a_{0}(\AA)$ & $x$ & $d \mathrm{~A}-\mathrm{O}_{8 \mathrm{~b}}$ & $d \mathrm{~A}-\mathrm{O}_{48 \mathrm{f}}$ & $d \mathrm{Ti}-\mathrm{O}_{48 \mathrm{f}}$ \\
\hline $\mathrm{La}_{2} \mathrm{Ti}_{2} \mathrm{O}_{7}$ & DFT-GGA & 10.52 & 0.322 & 2.27 & 2.64 & 2.00 \\
& HF [20] & 10.541 & 0.323 & - & 2.63 & 2.02 \\
& DFT-LDA [19] & 10.366 & 0.3227 & - & 2.59 & 1.98 \\
$\mathrm{Gd}_{2} \mathrm{Ti}_{2} \mathrm{O}_{7}$ & DFT-GGA & 10.23 & 0.329 & 2.22 & 2.51 & 1.97 \\
& Exp. [29] & 10.182 & 0.327 & & & \\
& Exp. [28] & 10.185 & 0.322 & & & \\
& Exp. [9] & 10.186 & 0.326 & & & \\
& MD [26] & 10.191 & & & 2.47 & \\
& MD [27] & 10.04 & 0.327 & & & \\
$\mathrm{Yb}_{2} \mathrm{Ti}_{2} \mathrm{O}_{7}$ & DFT-GGA & 10.2 & 0.325 & 2.21 & 2.53 & \\
& Exp. [9] & 10.032 & 0.331 & & & \\
\hline
\end{tabular}

antisites and oxygen migration for pyrochlores were observed experimentally. The defect structures of some pyrochlores have been investigated by several other simulations [18, 20, 27]. It was suggested that ionic motion will be affected predominantly by a vacancy hopping mechanism between $48 \mathrm{f}$ sites and the cation disorder is necessary for the thermal generation of anion vacancies on these sites. To develop a quantitative understanding of the trends involved in cation disorder and anion Frenkel disorder, here we calculated the formation energies of defects in $\mathrm{A}_{2} \mathrm{Ti}_{2} \mathrm{O}_{7}(\mathrm{~A}=\mathrm{La}, \mathrm{Gd}, \mathrm{Yb})$ pyrochlore based on a larger unit cell containing 88 atoms, considering the cation antisite and Frenkel-pair defects. The Frenkel pairs are formed by the reactions of $\mathrm{O}_{48 \mathrm{f}} \rightarrow \mathrm{V}_{48 \mathrm{f}}+\mathrm{O}_{8 \mathrm{a}}^{\prime \prime}$ and $\mathrm{O}_{8 \mathrm{~b}} \rightarrow \mathrm{V}_{8 \mathrm{~b}}+\mathrm{O}_{8 \mathrm{a}}^{\prime \prime}$. We found that such defect structures are not stable, and relaxing the structure will cause oxygen to return to its initial position. The cation-antisite disorder was simulated by the crystallographic site exchange of $\mathrm{A}$ and $\mathrm{Ti}$ ions around the $\mathrm{O}_{48 \mathrm{f}}$, where the defect formation energies were calculated using the following formula: $E_{\text {defect }}=E$ (relaxed bulk with defect) $-E$ (relaxed perfect bulk). From our calculations the formation energies were determined to be $1.343,2.063$ and $1.248 \mathrm{eV}$ for $\mathrm{La}_{2} \mathrm{Ti}_{2} \mathrm{O}_{7}, \mathrm{Gd}_{2} \mathrm{Ti}_{2} \mathrm{O}_{7}$ and $\mathrm{Yb}_{2} \mathrm{Ti}_{2} \mathrm{O}_{7}$, respectively. Obviously the cation antisite formation energy for $\mathrm{Yb}_{2} \mathrm{Ti}_{2} \mathrm{O}_{7}$ is the least among the three compositions. It seems that similar cationic radii can account for the results of $\mathrm{Yb}_{2} \mathrm{Ti}_{2} \mathrm{O}_{7}$, since an exchange between $\mathrm{Yb}^{3+}$ and $\mathrm{Ti}^{4+}$ should be more compatible and oxygen migration should be much easier than in $\mathrm{Gd}_{2} \mathrm{Ti}_{2} \mathrm{O}_{7}$ and $\mathrm{La}_{2} \mathrm{Ti}_{2} \mathrm{O}_{7}$ because of the greater similarity in cation size. Our results indicated that $\mathrm{Yb}_{2} \mathrm{Ti}_{2} \mathrm{O}_{7}$ compounds more easily form defect fluorite structures and exhibit higher radiation resistance. Sickafus et al [31] have determined the isolated cation antisite defect energy, as a function of $\mathrm{A}$ and $\mathrm{B}$ cation radii, for a wide range of $\mathrm{A}_{2} \mathrm{~B}_{2} \mathrm{O}_{7}$ compounds. They found the lowest defect energies are associated with compounds in which $\mathrm{A}$ and $\mathrm{B}$ radii are similar. Also, it was predicted that compounds with very dissimilar cationic radii should exhibit the greatest susceptibility to lattice destabilization (and possible amorphization), whereas compounds with similar radii should behave more robustly in a radiation environment. However, our calculations showed that the formation energies of antisite defects are not linearly dependent on the cation radii ratio, and the cation antisite formation energy is the largest for $\mathrm{Gd}_{2} \mathrm{Ti}_{2} \mathrm{O}_{7}$ pyrochlores. It was suggested that $\mathrm{Gd}_{2} \mathrm{Ti}_{2} \mathrm{O}_{7}$ compound is the least likely to form a defect fluorite structure, which gives rise to the least resistance to radiation-induced amorphization. These results are consistent with the experimental observation $[4,9,10,16]$ that $\mathrm{Gd}_{2} \mathrm{Ti}_{2} \mathrm{O}_{7}$ pyrochlore is the most readily amorphized under irradiation. 

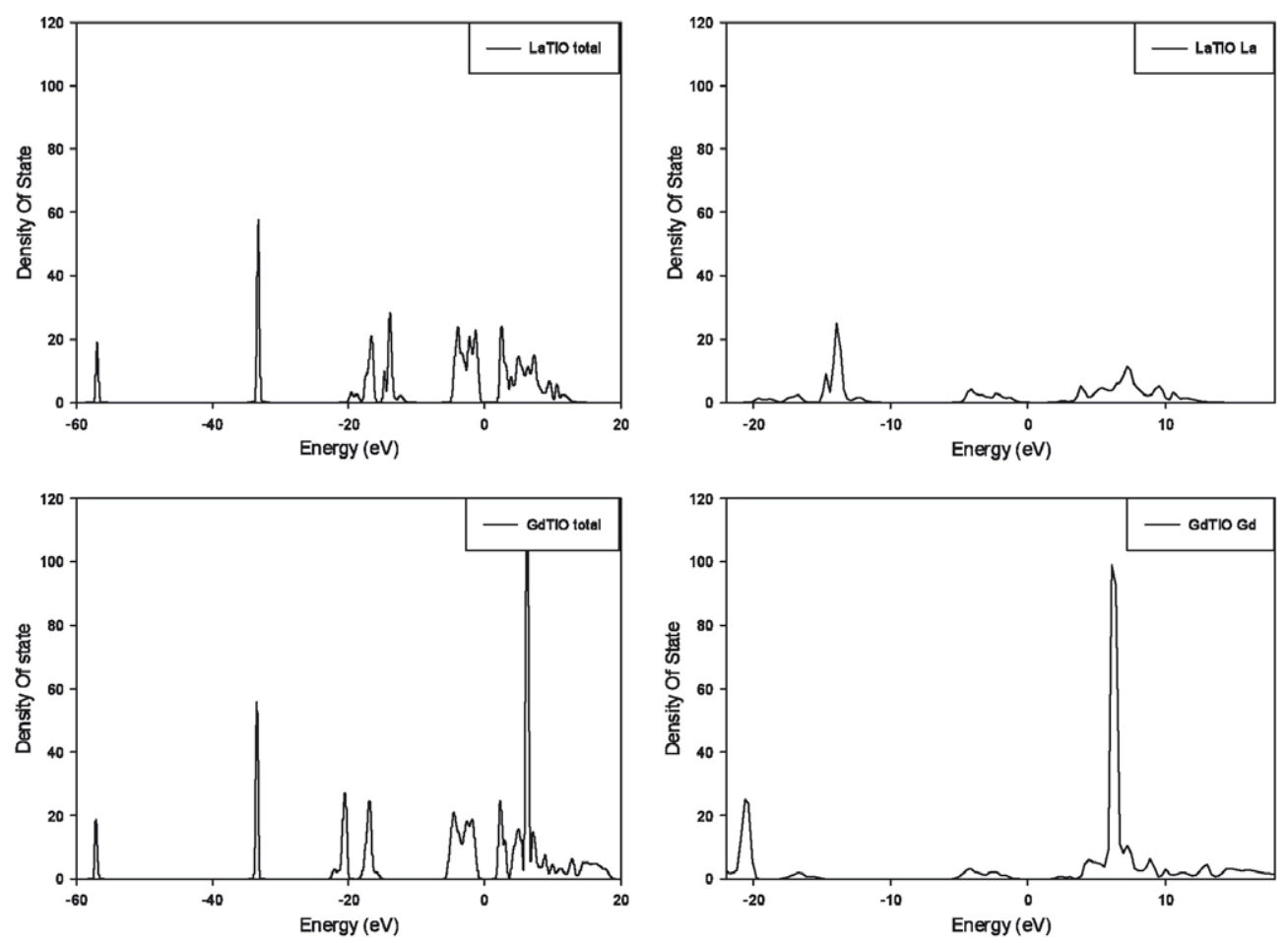

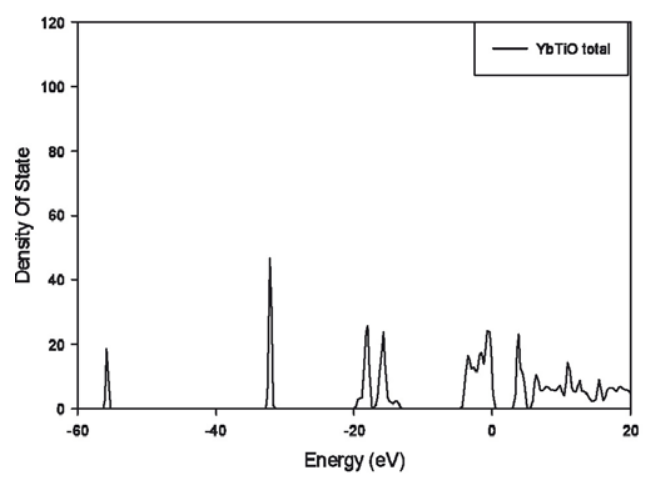

(a)

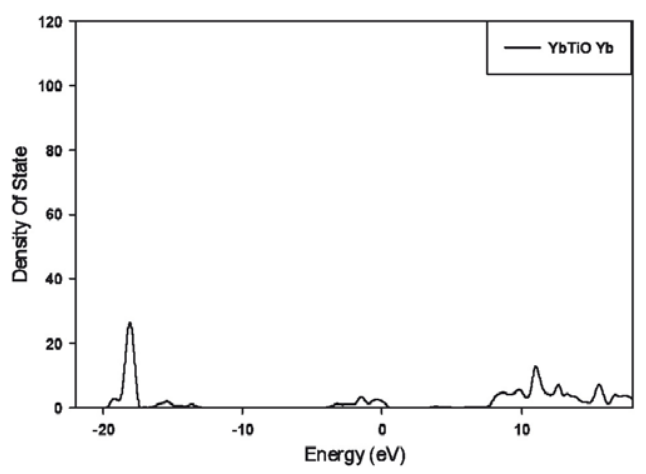

(b)

Figure 2. (a) Total DOS curves for $\mathrm{A}_{2} \mathrm{Ti}_{2} \mathrm{O}_{7}(\mathrm{~A}=\mathrm{La}, \mathrm{Gd}$ and $\mathrm{Yb})$. (b) DOS curves at $\mathrm{O}$ atoms for $\mathrm{A}_{2} \mathrm{Ti}_{2} \mathrm{O}_{7}(\mathrm{~A}=\mathrm{La}, \mathrm{Gd}$ and $\mathrm{Yb})$. (c) DOS curves at Ti atoms for $\mathrm{A}_{2} \mathrm{Ti}_{2} \mathrm{O}_{7}(\mathrm{~A}=\mathrm{La}, \mathrm{Gd}$ and $\mathrm{Yb})$.

\subsection{Electronic properties}

3.3.1. Density of state (DOS) analysis. Figure 2 shows the total DOS of $\mathrm{A}_{2} \mathrm{Ti}_{2} \mathrm{O}_{7}(\mathrm{~A}=\mathrm{La}$, $\mathrm{Gd}$ and $\mathrm{Yb}$ ) compounds and partial DOS at elements occupying A sites, oxygen and Ti atoms. The Fermi level is set to $0 \mathrm{eV}$. It is interesting to find that $\mathrm{La}_{2} \mathrm{Ti}_{2} \mathrm{O}_{7}$ and $\mathrm{Yb}_{2} \mathrm{Ti}_{2} \mathrm{O}_{7}$ present similar densities of states, while the $\mathrm{Gd}_{2} \mathrm{Ti}_{2} \mathrm{O}_{7}$ compound shows a much different character. Figure 2(b) shows the partial DOS at A elements. The 5P orbitals occur at $-13.93,-20.64$ and $-17.99 \mathrm{eV}$ for $\mathrm{La}_{2} \mathrm{Ti}_{2} \mathrm{O}_{7}, \mathrm{Gd}_{2} \mathrm{Ti}_{2} \mathrm{O}_{7}$ and $\mathrm{Yb}_{2} \mathrm{Ti}_{2} \mathrm{O}_{7}$, respectively. It was noticeable that the conduction bands of $\mathrm{Gd}$ differ greatly from those of $\mathrm{La}$ and $\mathrm{Yb}$. A strong peak representing 

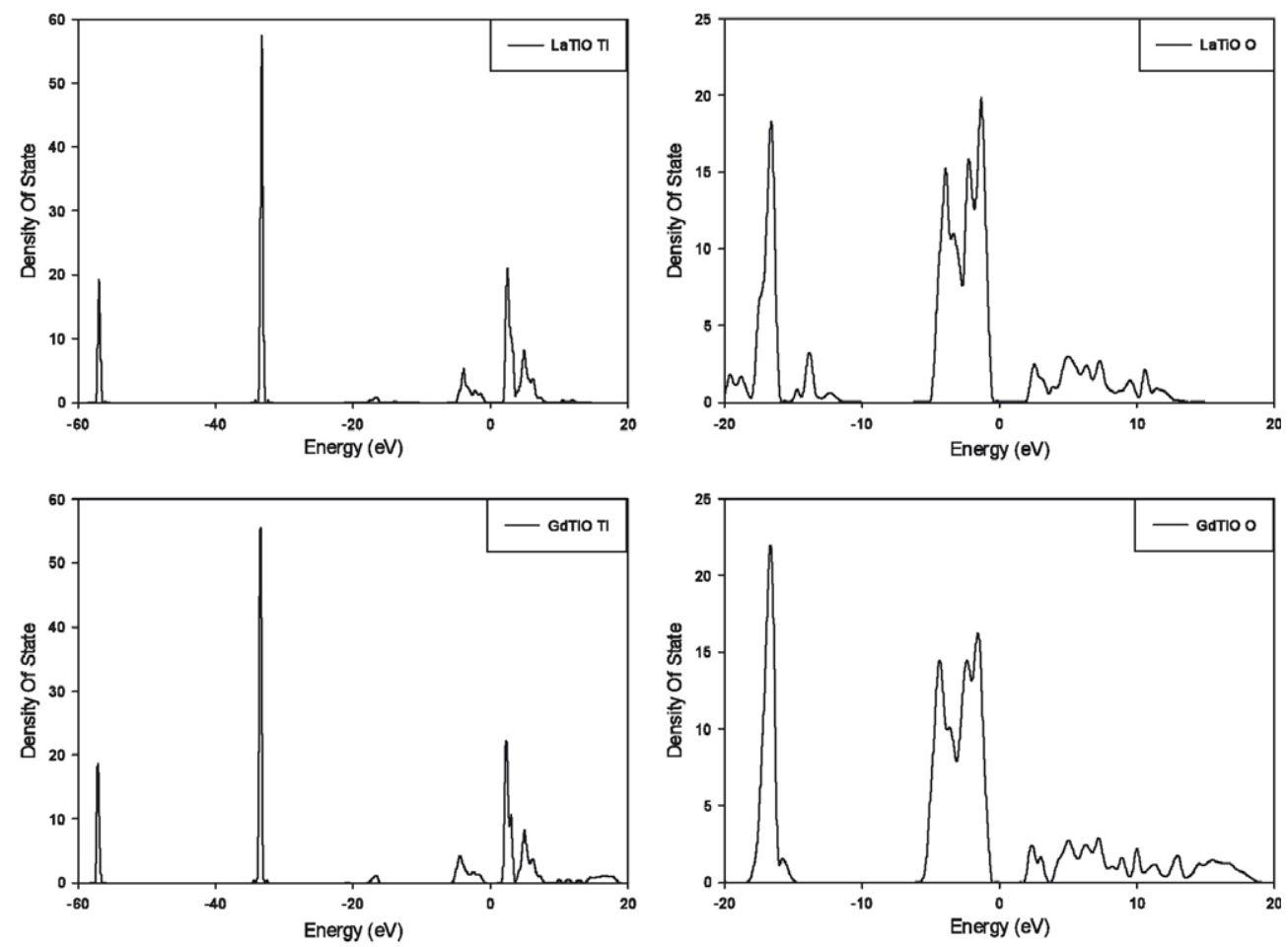

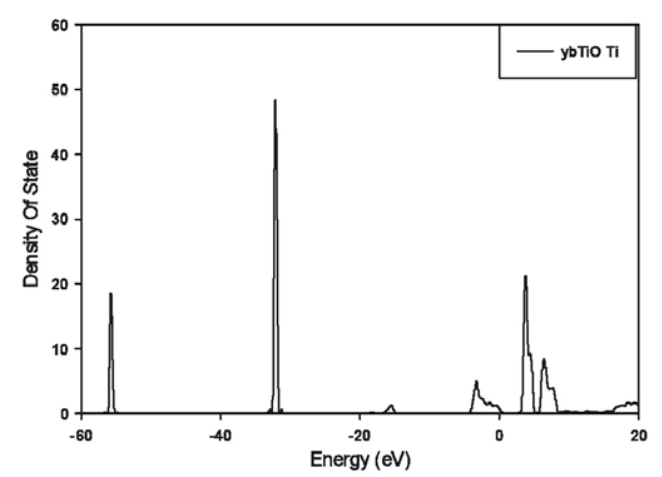

(c)

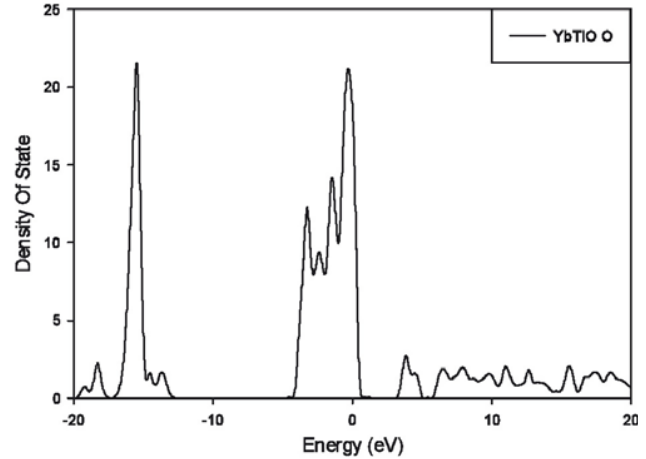

(d)

Figure 2. (Continued.)

6S orbitals was observed for $\mathrm{Gd}_{2} \mathrm{Ti}_{2} \mathrm{O}_{7}$, whereas such a strong peak does not exist for $\mathrm{La}$ and Yb. As can be seen from figure 2(c), the oxygen 2S-derived state appears at $-16.51,-16.73$ and $-15.43 \mathrm{eV}$ for the same sequence. The second peaks in figure 2 (c) represent oxygen $2 \mathrm{P}$ derived states. These states appear at $-3.88,-2.33$ and $-1.30 \mathrm{eV}$ for $\mathrm{La}_{2} \mathrm{Ti}_{2} \mathrm{O}_{7},-4.47,-2.25$ and $-1.69 \mathrm{eV}$ for $\mathrm{Gd}_{2} \mathrm{Ti}_{2} \mathrm{O}_{7}$, and $-3.23,-1.52$ and $-0.39 \mathrm{eV}$ for $\mathrm{Yb}_{2} \mathrm{Ti}_{2} \mathrm{O}_{7}$. The DOS curves at $\mathrm{Ti}$ atoms show similar characters to each other. As can be seen from figure 2, the energy peaks of $\mathrm{Gd}_{2} \mathrm{Ti}_{2} \mathrm{O}_{7}$ generally shifted downwards in energy relative to the corresponding orbital peaks of $\mathrm{La}_{2} \mathrm{Ti}_{2} \mathrm{O}_{7}$ and $\mathrm{Yb}_{2} \mathrm{Ti}_{2} \mathrm{O}_{7}$, meaning that stronger interaction exits between oxygen and cations in $\mathrm{Gd}_{2} \mathrm{Ti}_{2} \mathrm{O}_{7}$. Also, the most striking character observed for $\mathrm{Gd}_{2} \mathrm{Ti}_{2} \mathrm{O}_{7}$ is the bands above the Fermi level composed of peaks due to the significant contributions of $\mathrm{Gd}$ 
Table 2. Calculated atomic Hirshfeld charge $(|e|)$ for $\mathrm{A}_{2} \mathrm{Ti}_{2} \mathrm{O}_{7}(\mathrm{~A}=\mathrm{La}, \mathrm{Gd}, \mathrm{Yb})$ compounds.

\begin{tabular}{llll}
\hline & $\mathrm{La}_{2} \mathrm{Ti}_{2} \mathrm{O}_{7}$ & $\mathrm{Gd}_{2} \mathrm{Ti}_{2} \mathrm{O}_{7}$ & $\mathrm{Yb}_{2} \mathrm{Ti}_{2} \mathrm{O}_{7}$ \\
\hline $\mathrm{A}$ & +0.38 & +0.35 & +0.42 \\
$\mathrm{Ti}$ & +0.65 & +0.60 & +0.57 \\
$\mathrm{O}_{48 \mathrm{f}}$ & -0.28 & -0.27 & -0.27 \\
$\mathrm{O}_{8 \mathrm{~b}}$ & -0.38 & -0.26 & -0.37 \\
\hline
\end{tabular}

Table 3. Overlap populations $(|e|)$ for $\mathrm{A}_{2} \mathrm{Ti}_{2} \mathrm{O}_{7}(\mathrm{~A}=\mathrm{La}, \mathrm{Gd}, \mathrm{Yb})$.

\begin{tabular}{llll}
\hline & $\mathrm{La}_{2} \mathrm{Ti}_{2} \mathrm{O}_{7}$ & $\mathrm{Gd}_{2} \mathrm{Ti}_{2} \mathrm{O}_{7}$ & $\mathrm{Yb}_{2} \mathrm{Ti}_{2} \mathrm{O}_{7}$ \\
\hline $\mathrm{A}-\mathrm{O}_{48 \mathrm{f}}$ & 0.10 & 0.05 & 0.08 \\
$\mathrm{~A}-\mathrm{O}_{8 \mathrm{~b}}$ & 0.17 & 0.05 & 0.07 \\
$\mathrm{Ti}-\mathrm{O}_{48 \mathrm{f}}$ & 0.15 & 0.16 & 0.16 \\
\hline
\end{tabular}

6s and small contributions of other orbitals, which is much different from those of $\mathrm{La}_{2} \mathrm{Ti}_{2} \mathrm{O}_{7}$ and $\mathrm{Yb}_{2} \mathrm{Ti}_{2} \mathrm{O}_{7}$. Since $\mathrm{Gd}_{2} \mathrm{Ti}_{2} \mathrm{O}_{7}$ is the most readily amorphized under certain irradiation environments $[4,9,10,16]$, we suggest that the electronic structures may have a great effect on their radiation-induced response behavior.

3.3.2. The electronic band structure. The calculated electronic band structures of $\mathrm{A}_{2} \mathrm{Ti}_{2} \mathrm{O}_{7}$ $(\mathrm{R}=\mathrm{La}, \mathrm{Gd}$ and $\mathrm{Yb})$ pyrochlore compounds were given in figure 3. As can be seen, all the compounds present similar electronic band structures. It was shown that all the compounds have a direct band gap at the $\Gamma(000)$ point in the Brillouin zone, similar to the calculations of $\mathrm{La}_{2} \mathrm{Zr}_{2} \mathrm{O}_{7}$ and $\mathrm{La}_{2} \mathrm{Hf}_{2} \mathrm{O}_{7}$ reported by Terki et al [32]. The valence band maximum was estimated to be $-0.09,-0.12$ and $0.19 \mathrm{eV}$, and the conduction band minimum was 2.62, 2.59 and $3.14 \mathrm{eV}$ for $\mathrm{La}_{2} \mathrm{Ti}_{2} \mathrm{O}_{7}, \mathrm{Gd}_{2} \mathrm{Ti}_{2} \mathrm{O}_{7}$ and $\mathrm{Yb}_{2} \mathrm{Ti}_{2} \mathrm{O}_{7}$, respectively. This resulted in band gaps of 2.71, 2.71 and $3.34 \mathrm{eV}$, which indicated that all the compounds have semiconducting properties. It was noted that the Fermi level in $\mathrm{Yb}_{2} \mathrm{Ti}_{2} \mathrm{O}_{7}$ compound goes slightly across the valence bands, showing metallic character. This observation differs greatly from the experimental measurement that $\mathrm{Yb}_{2} \mathrm{Ti}_{2} \mathrm{O}_{7}$ pyrochlores are insulators. Such a discrepancy may be due to the fact that the structure considered is ideal without a cation antisite or other defects, while the real structure may be distorted or defective. The band gaps of $\mathrm{La}_{2} \mathrm{Zr}_{2} \mathrm{O}_{7}$ and $\mathrm{La}_{2} \mathrm{Hf}_{2} \mathrm{O}_{7}$ have been calculated to be 3.98 and $3.14 \mathrm{eV}$ by Terki et al [32].

3.3.3. Hirshfeld charge and overlap population analysis. Based on the optimized geometries, we calculated the Hirshfeld charges and performed overlap population analysis. Although it is widely accepted that the absolute magnitude of the atomic charges have little physical meaning as the results are sensitive to the atomic basis set with which they are calculated [33, 34], the consideration of relative values, in contrast to the absolute magnitudes, can yield useful information [35]. The calculated Hirshfeld charges are listed in table 2. The total charge on the A cation was determined to be $+0.38|e|,+0.35|e|$ and $+0.42|e|$ in $\mathrm{La}_{2} \mathrm{Ti}_{2} \mathrm{O}_{7}, \mathrm{Gd}_{2} \mathrm{Ti}_{2} \mathrm{O}_{7}$ and $\mathrm{Yb}_{2} \mathrm{Ti}_{2} \mathrm{O}_{7}$, respectively. For the $8 \mathrm{~b}$ oxygen anion our calculations yielded a total charge of $-0.38|e|,-0.26|e|$ and $-0.37|e|$ for the same sequence. This value was determined to be $-0.28|e|,-0.27|e|$ and $-0.27|e|$ for the $48 \mathrm{f}$ oxygen anion. It is obvious that the interactions between the A cation and oxygen anion are more ionic for $\mathrm{Gd}_{2} \mathrm{Ti}_{2} \mathrm{O}_{7}$ than the corresponding bonds in $\mathrm{La}_{2} \mathrm{Ti}_{2} \mathrm{O}_{7}$ and $\mathrm{Yb}_{2} \mathrm{Ti}_{2} \mathrm{O}_{7}$. The same conclusion can be obtained from overlap population analysis. Table 3 shows the overlap populations for nearest neighbours in 


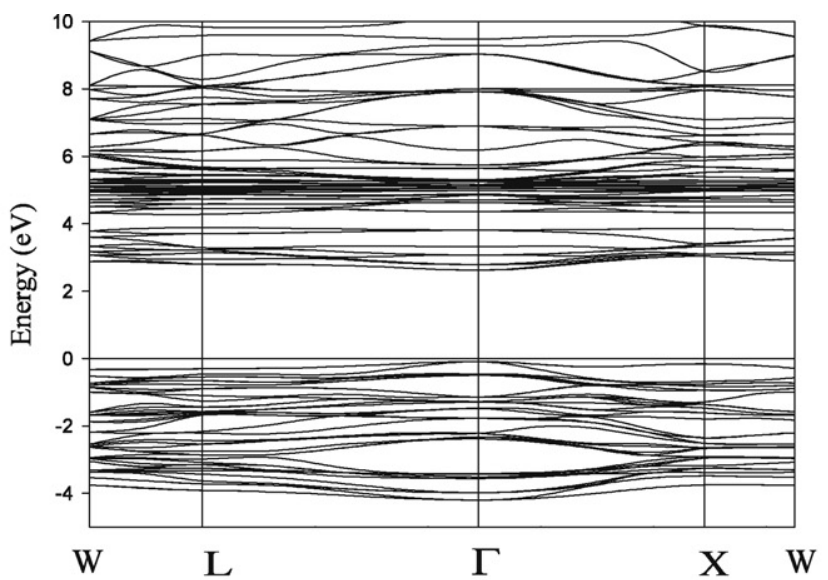

(a) $\mathrm{La} 2 \mathrm{Ti} 2 \mathrm{O} 7$

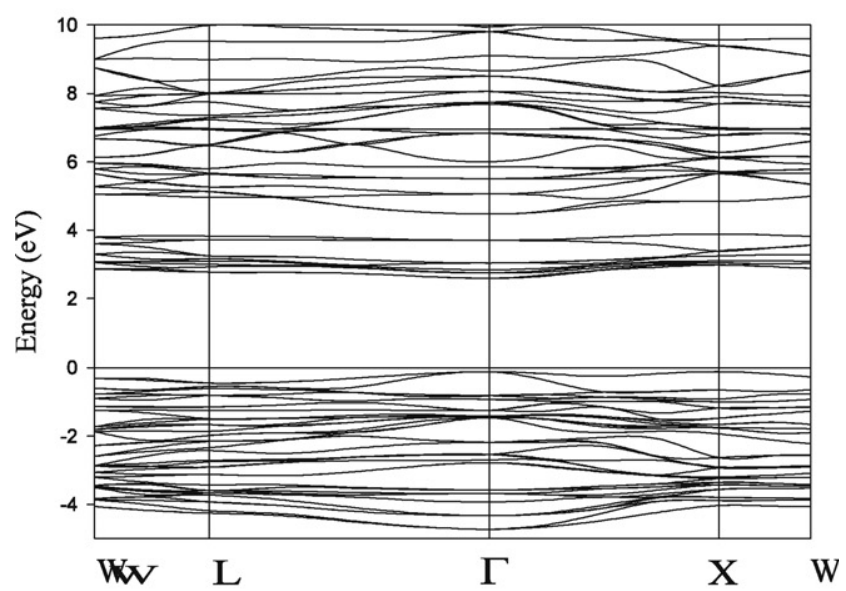

(b) Gd2Ti2O7

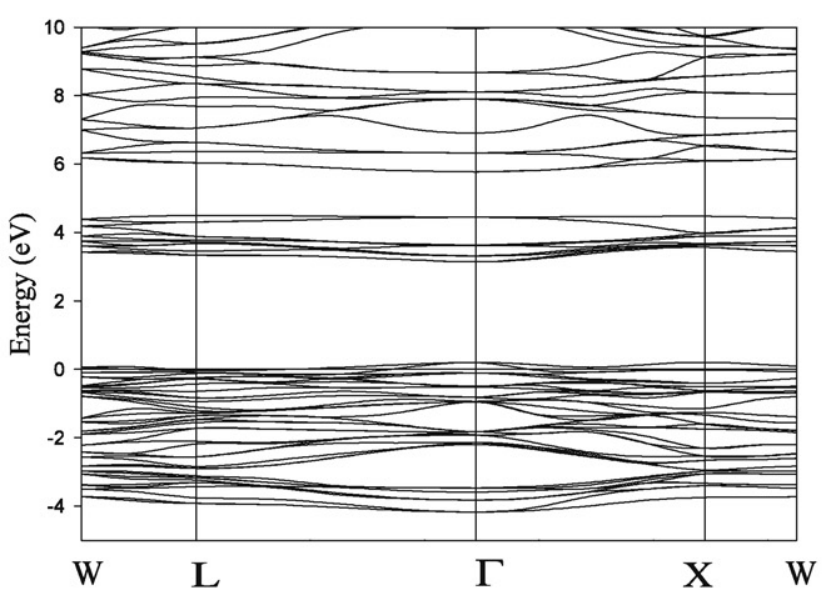

(c) $\mathrm{Yb} 2 \mathrm{Ti} 2 \mathrm{O} 7$

Figure 3. The calculated electronic band structure for $\mathrm{A}_{2} \mathrm{Ti}_{2} \mathrm{O}_{7}(\mathrm{~A}=\mathrm{La}, \mathrm{Gd}$ and $\mathrm{Yb})$. 
the pyrochlores. A value for the overlap population close to zero indicates that there is no significant interaction between the electronic populations of the two atoms and a high overlap indicates a high degree of covalency in the bond. The overlap populations between nearest A cation and $\mathrm{O}_{48 \mathrm{f}}$ atoms were determined to be $0.1|e|, 0.05|e|$ and $0.08|e|$ for $\mathrm{La}_{2} \mathrm{Ti}_{2} \mathrm{O}_{7}$, $\mathrm{Gd}_{2} \mathrm{Ti}_{2} \mathrm{O}_{7}$ and $\mathrm{Yb}_{2} \mathrm{Ti}_{2} \mathrm{O}_{7}$, respectively. For the $\mathrm{A}-\mathrm{O}_{8 \mathrm{~b}}$ bond the populations are $0.17|e|, 0.05|e|$ and $0.07|e|$. These results also suggested that the $\mathrm{A}-\mathrm{O}_{48 \mathrm{f}}$ and $\mathrm{A}-\mathrm{O}_{8 \mathrm{~b}}$ bonds in $\mathrm{Gd}_{2} \mathrm{Ti}_{2} \mathrm{O}_{7}$ are slightly more ionic than the corresponding bonds in $\mathrm{La}_{2} \mathrm{Ti}_{2} \mathrm{O}_{7}$ and $\mathrm{Yb}_{2} \mathrm{Ti}_{2} \mathrm{O}_{7}$. From table 3 it can also be found that although the $\mathrm{Ti}-\mathrm{O}_{48 \mathrm{f}}$ interactions are relatively stronger than $\mathrm{A}-\mathrm{O}_{48 \mathrm{f}}$ for all compounds, the interactions between nearest $\mathrm{Ti}$ and $\mathrm{O}_{48 \mathrm{f}}$ atoms are nearly the same for these three compounds. We also calculated static charges with the Voronoi deformation density (VDD) method. Fonseca-Guerra et al [38] have showed that this method can give chemically meaningful charges with basis-set independence. The bond type and strength obtained with the VDD method are similar to the results obtained from the Hirshfeld method. Terki et al [35] also observed that the $\mathrm{B}-\mathrm{O}$ covalent interaction is stronger than that of $\mathrm{La}-\mathrm{O}$ bond for $\mathrm{La}_{2} \mathrm{Zr}_{2} \mathrm{O}_{7}$ and $\mathrm{La}_{2} \mathrm{Hf}_{2} \mathrm{O}_{7}$. Some investigations $[35,36]$ demonstrated that the resistance of a complex nonmetallic material to amorphization by resistance to radiation damage is generally governed by the competition between the short-range covalent and long-range ionic forces and the more covalently bonded materials are more readily amorphized at lower temperatures under heavy ion irradiation. It seems that our calculations do not support this conclusion. Experimentally, it was also proposed that [9] $\mathrm{Ti}-\mathrm{O}_{48 \mathrm{f}}$ may play significant role in determining their radiation response behavior. Since f electrons of the A cation were not considered in this work, we will perform further calculations to investigate the effects of $\mathrm{f}$ electrons of the A cation on their electronic structures.

\section{Summary}

In this work first-principles studies using a plane-wave pseudopotential method based on DFT were carried out on $\mathrm{A}_{2} \mathrm{Ti}_{2} \mathrm{O}_{7}(\mathrm{~A}=\mathrm{La}, \mathrm{Gd}, \mathrm{Yb})$ pyrochlore compounds. The structural, energetic and electronic properties of these compounds all have been calculated and analyzed. The calculated structural parameters of $\mathrm{La}_{2} \mathrm{Ti}_{2} \mathrm{O}_{7}$ and $\mathrm{Gd}_{2} \mathrm{Ti}_{2} \mathrm{O}_{7}$ compounds are in accordance with most theoretical studies, whereas the optimized lattice constant of $\mathrm{Yb}_{2} \mathrm{Ti}_{2} \mathrm{O}_{7}$ is about $1.67 \%$ larger than the experimental value. The calculated defect formation energies showed that the formation energies of antisite defects are not linearly dependent on the cation radii ratio, and, among the three compositions, the cation antisite formation energy is the largest for $\mathrm{Gd}_{2} \mathrm{Ti}_{2} \mathrm{O}_{7}$ pyrochlore. It was indicated that $\mathrm{Gd}_{2} \mathrm{Ti}_{2} \mathrm{O}_{7}$ compound is the least likely to form a defect fluorite structure, which gives rise to the least resistance to radiation-induced amorphization. We also found $\mathrm{La}_{2} \mathrm{Ti}_{2} \mathrm{O}_{7}$ and $\mathrm{Yb}_{2} \mathrm{Ti}_{2} \mathrm{O}_{7}$ to have similar density of states, while $\mathrm{Gd}_{2} \mathrm{Ti}_{2} \mathrm{O}_{7}$ compound shows a much different character. It was suggested that the electronic structure of the A cation and the bond type may have certain influences on the behavior of $\mathrm{A}_{2} \mathrm{Ti}_{2} \mathrm{O}_{7}(\mathrm{~A}=\mathrm{La}, \mathrm{Gd}, \mathrm{Yb})$ pyrochlores in response to irradiation.

\section{Acknowledgments}

This work was supported by the Office of Basic Energy Sciences, US DOE, grant no. DEFG02-97ER45656 (RCE) and National Science Foundation of China (10647111).

\section{References}

[1] Subramanian M A, Aravamudan G and Rao G V S 1983 Prog. Solid State Chem. 1555

[2] Kung H H, Jarrett J S, Sleight A W and Ferretti A 1977 J. Appl. Phys. 482463

[3] Ewing R C, Weber W J and Lian J 2004 J. Appl. Phys. 955949 
[4] Lian J, Wang L M, Ewing R C and Boatner L A 2006 Nucl. Instrum. Methods B 242448

[5] Begg B D, Hess N J, McCready D E, Thevuthasan S and Weber W J 2001 J. Nucl. Mater. 289188

[6] Wang S X, Wang L M, Ewing R C, Was G S and Lumpkin G R 1999 Nucl. Instrum. Methods B 148704

[7] Wang S X, Begg B D, Wang L M, Ewing R C, Weber W J and Kutty K V G 1999 J. Mater. Res. 144470

[8] Meldrum A, White C W, Keppens V, Boatner L A and Ewing R C 2001 Phys. Rev. B 63104109

[9] Lian J, Chen J, Wang L M, Ewing R C, Farmer J M, Boatner L A and Helean K B 2003 Phys. Rev. B 68134107

[10] Lian J, Wang L M, Chen J, Sun K, Ewing R C, Farmer J M and Boatner L A 2003 Acta. Mater. 511493

[11] Nachimuthu P, Thevuthasan S, Shutthanandan V, Adams E M, Weber W J, Begg B D, Shuh D K, Lindle D W, Gullikson E M and Perera R C C 2005 J. Appl. Phys. 97033518

[12] Nachimuthu P, Thevuthasan S, Engelhard M H, Weber W J, Shuh D K, Hamdan N M, Mun B S, Adams E M, McCready D E, Shutthanandan V, Lindle D W, Balakrishnan G, Paul D M, Gullikson E M, Perera R C C, Lian J, Wang L M and Ewing R C 2004 Phys. Rev. B 70100101

[13] Lian J, Wang L M, Ewing R C and Boatner L A 2005 Nucl. Instrum. Methods B 241365

[14] Chen J, Lian J, Wang L M, Ewing R C and Boatner L A 2001 Appl. Phys. Lett. 791989

[15] Chen J, Lian J, Wang L M, Ewing R C, Wang R G and Pan W 2002 Phys. Rev. Lett. 88105901

[16] Wang S X, Begg B D, Wang L M, Ewing R C, Weber W J and Kutty K V G 1999 J. Mater. Res. 144470

[17] Pirzada M, Grimes R W, Minervini L, Maguire J F and Sickafus K E 2001 Solid State Ion. 140201

[18] Panero W R, Stixrude L and Ewing R C 2004 Phys. Rev. B 70054110

[19] Pruneda J M and Artacho E 2005 Phys. Rev. B 72085107

[20] Chartier A, Meis C, Weber W J and Corrales L R 2002 Phys. Rev. B 65134116

[21] Nemoshkalenko V V, Borisenko S V, Uvarov V N, Yaresko A N, Vakhney A G, Senkevich A I, Bondarenko T N and Borisenko V D 2001 Phys. Rev. B 63075106

[22] Perdew J P, Chevary J P, Vosko S H, Jackson K A, Pederson M R, Singh D J and Fiolhais C 1992 Phys. Rev. B 466671

[23] White J A and Bird D M 1994 Phys. Rev. B 504954

[24] Kresse G and Joubert J 1999 Phys. Rev. B 591758

[25] Minervini L, Grimes R W and Sickafus K E 2000 J. Am. Ceram. Soc. 831873

[26] Purton J A and Allan N L 2002 J. Mater. Chem. 122923

[27] Wilde P J and Catlow C R A 1998 Solid State Ion. 112173

[28] Subramanian M A, Aravamudan G and Rao G V S 1983 Prog. Solid State Chem. 1555

[29] Tabira Y, Withers R L, Minervini L and Grimes R W 2000 J. Solid State Chem. 15316

[30] Kennedy B J, Hunter B A and Howard C J 1997 J. Solid State Chem. 13058

[31] Sickafus K E, Minervini L, Grimes R W, Valdez J A, Ishimaru M, Li F, McClellan K J and Hartmann T 2000 Science 289748

[32] Terki R, Feraoun H, Bertrand G and Aourag H 2004 J. Appl. Phys. 966482

[33] Segall M D, Pickard C J, Shah R and Payne M C 1996 Mol. Phys. 89571

[34] Davidson E R and Chakravorty S 1992 Theor. Chim. Acta 83319

[35] Segall M D, Shah R, Pickard C J and Payne M C 1996 Phys. Rev. B 5416317

[36] Naguib H M and Kelly R 1975 Radiat. Eff. 251

[37] Trachenko K 2004 J. Phys.: Condens. Matter 16 R1491

[38] Guerra C F, Handgraaf J-W, Baerends E J and Bickelhaupt F M 2003 J. Comput. Chem. 25189 